\title{
PELATIHAN KONSELING BAGI KOMUNITAS PEMERHATI KELUARGA KATOLIK DI JAKARTA
}

\author{
Widya Risnawaty ${ }^{1}$ dan Denrich Suryadi ${ }^{2}$ \\ ${ }^{1}$ Fakultas Psikologi, Universitas Tarumanagara \\ Email: widyar@fpsi.untar.id \\ ${ }^{2}$ Fakultas Psikologi, Universitas Tarumanagara \\ Email: denrichs@fpsi.untar.ac.id
}

\begin{abstract}
The family, as the smallest unit in society, is the main foundation of healthy and mature personal growth. Therefore, the functioning of the family must be kept and maintained. But in reality, every family faces various challenges. The Catholic Church is very concerned and strives to keep the Catholic family survive and carry out its functions properly. One effort undertaken by the Jakarta Archdiocese Family Apostolic Commission (Kom-KK KAJ) is to provide assistance for families who are having psychological problems in the form of counseling by trained lay counselors. The purpose of this PKM activity is to address the needs of partners related to the importance of knowing how to do counseling in a non-professional context. These lay counselors are non-professionals who have a concern to help others, especially in terms of family assistance. Therefore, Kom-KK KAJ believes that these lay counselors need to be equipped with basic knowledge about the process and how to provide basic counseling so that they can immediately provide assistance. The PKM activities carried out took the form of 16 hours of basic training divided into 2 days of implementation. The number of participants participated was 20 participants. Training is given in the form of theory (60\%) and practice (40\%). Related to the training material provided includes: knowledge of lay counselors and Community Observer Communities, basic theories in counseling, and basic counseling skills include interviews, observation, active listening, paraphrasing, problem identification and empowerment of counselee. The results show that there is a significant difference between before being given an intervention and afterwards.
\end{abstract}

Keyword: Counseling training; lay counselor; family

\begin{abstract}
ABSTRAK
Keluarga, sebagai unit terkecil dalam masyarakat menjadi fondasi utama pertumbuhan pribadi yang sehat dan matang. Oleh karena itu keberfungsian keluarga harus terus dijaga dan dipelihara. Namun pada kenyataanya, setiap keluarga menghadapi tantangan yang beragam. Gereja Katolik sangat peduli dan berupaya untuk menjaga agar keluarga Katolik tetap dapat bertahan dan menjalankan fungsinya dengan baik. Salah satu upaya yang dilakukan oleh Komisi Kerasulan Keluarga Keuskupan Agung Jakarta (Kom-KK KAJ) adalah memberikan pendampingan bagi keluarga yang sedang memiliki masalah psikologis dalam bentuk konseling yang dilakukan oleh para konselor awam terlatih. Tujuan diselenggarakannya kegiatan PKM ini guna menjawab kebutuhan mitra terkait dengan pentingnya mengetahui cara melakukan konseling dalam konteks non-profesional. Para konselor awam ini adalah para nonprofesional yang memiliki kepedulian untuk membantu sesama khususnya dalam hal pendampingan keluarga. Oleh karenanya, KOM-KK KAJ berpendapat bahwa para konselor awam ini perlu dibekali dengan pengetahuan dasar mengenai proses dan cara pemberian konseling dasar agar segera dapat memberikan bantuan pendampingan. Kegiatan PKM yang dilangsungkan berbentuk pelatihan dasar selama 16 jam yang terbagi dalam 2 hari pelaksanaan. Adapun jumlah peserta ikut serta sebanyak 20 orang peserta. Pelatihan diberikan dalam bentuk teori (60\%) dan praktik (40\%). Terkait dengan materi pelatihan yang diberikan meliputi: pengetahuan mengenai konselor awam dan Komunitas Pemerhati Keluarga, dasar-dasar teori dalam konseling, dan ketrampilan dasar konseling meliputi wawancara, observasi, mendengarkan aktif, memparaphrasekan, identifikasi masalah dan pemberdayaan konseli. Hasilnya menunjukkan bahwa terdapat perbedaan yang signifikan antara sebelum diberikan intervensi dan sesudahnya.
\end{abstract}

Kata kunci: Pelatihan konseling; konselor awam; keluarga

\section{PENDAHULUAN}

Keluarga secara konseptual dapat dijelaskan sebagai suatu unit terkecil yang paling mendasar dalam kehidupan sosial manusia (Brown \& Brown, 2003 dikutip dalam Samuel, Rillota \& Brown, 
2012). Pernyataan tersebut diartikan mengandung makna bahwa berfungsinya keluarga secara sehat dapat memberikan kontribusi terhadap kehidupan bermasyarakat yang sehat. Mengacu pada tulisan dari Soetjiningsih (1995), pada prinsipnya keluarga diharapkan mampu berfungsi untuk mewujudkan proses pengembangan interaksi antara anggota keluarga, kerabat dan antar generasi yang didasarkan pada cinta kasih sehingga keluarga dapat bertumbuh secara harmonis.

Dalam ajaran agama pada umumnya keluarga menjadi fokus perhatian. Merujuk pada ajaran Gereja Katolik, keluarga mendapatkan perhatian khusus dan penting. Keluarga merupakan fondasi bagi setiap anggota keluarga untuk tumbuh dan berkembang menjadi pribadi yang utuh didasari oleh cinta kasih. Oleh karenanya keluarga menjadi media utama dan pertama sebagai tempat pertumbuhan dan perlindungan bagi setiap anggota keluarga yang ada di dalamnya. Setiap keluarga, khususnya pasangan suami-istri yang telah terpanggil untuk membentuk keluarga harus mengusahakan kesejahteraan hidup seluruh anggota keluarga didasarkan pada nilai-nilai moral dan spiritualitas (Tim Pusat Pendampingan Keluarga "Brayat Minulyo", 2007; Habur, 2018).

Alasan lain yang menjadi dasar kepedulian Gereja Katolik terhadap kehidupan keluarga merujuk pada sifat-sifat perkawinan Katolik, yaitu (Suharyanto dalam Tim Pusat Pendampingan Keluarga "Brayat Minulyo", 2007) terbentuknya kesatuan antara laki-laki dan perempuan dalam ikatan perkawinan yang bersifat eksklusif dan tidak bisa terceraikan oleh manusia. Artinya Gereja Katolik tidak menghendaki adanya hubungan lain di luar pernikahan (poligami dan perselingkuhan) ataupun perceraian. Berdasarkan sifat dasar perkawinan Katolik tersebut, Gereja Katolik sangat memedulikan kesejahteraan keluarga dan anggota-anggotanya agar terus dapat mengupayakan kesatuan dan keutuhan keluarga, agar setiap anggota keluarga yang ada di dalamnya dapat bertumbuh menjadi pribadi yang utuh dalam keluarga yang harmonis.

Tak dapat dipungkiri bahwa setiap keluarga memiliki masalah, mulai dari intensitas yang ringan hingga berat. Tidak sedikit keluarga yang mengalami tantangan begitu berat, baik terkait dengan masalah finansial, pengasuhan, konflik antar anggota keluarga seperti konflik antar suami-istri ataupun orangtua dan anak, kekerasan dalam rumah tangga, pengabaian tanggungjawab sehingga mengganggu fungsi peran dari masing-masing anggota keluarga (Lestari, 2012).

Bentuk sikap kepedulian Gereja Katolik tersebut diwujudkan dalam aksi nyata dengan membentuk komisi-komisi yang diperbantukan untuk mendampingi kehidupan keluarga Katolik. Salah satu komisi yang dibentuk oleh Keuskupan Agung Jakarta adalah Komisi Kerasulan Keluarga atau biasa disingkat menjadi KOM-KK (Keuskupan Agung Jakarta, 2018). KOM-KK adalah komisi dalam Keuskupan yang berperan dalam mendampingi keluarga-keluarga katolik. Bentuk pedampingan yang diberikan bersifat preventif dan kuratif. Tindakan preventif umumnya berbentuk psikoedukasi, sedangkan tindakan kuratif biasanya diwujudkan dalam bentuk pendampingan konseling. Tindakan kuratif ditujukan bagi keluarga-keluarga yang sedang mengalami disfungsi. Salah satu bentuk bantuan yang diberikan adalah layanan konseling.

Idealnya layanan konseling diberikan oleh para profesional seperti Konselor profesional, Psikolog, Psikiater, Psikoterapis dan Dokter. Namun sayangnya jumlah profesional yang berkarya dalam memberikan pelayanan di Gereja tidak sebanding dengan jumlah keluarga-keluarga yang membutuhkan bantuan. Untuk mengatasi kebutuhan pelayanan umat yang sangat banyak, Gereja mengajak para awam yang peduli dan memiliki kemauan untuk membantu sesamanya untuk bergabung dalam kelompok konselor awam dalam memberikan layanan pastoral. Apriano (2018), dalam penelitiannya menyebutkan bahwa layanan konseling pastoral saat ini sudah bergeser. Layanan pastoral tidak lagi hanya dilakukan oleh Pastor atau Pendeta saja, karena akan sulit 
menjangkau seluruh umat yang jumlahnya sangat banyak. Oleh karenanya layanan pastoral saat ini telah melibatkan awam sebagai konselor awam. Layanan pastoral saat ini bersifat komunal.

Dalam Gereja Katolik, konselor awam ini kemudian bergabung dalam Komunitas Pemerhati Keluarga, yaitu komunitas yang memiliki kepedulian pada keluarga-keluarga yang membutuhkan bantuan. Tugas utama Komunitas Pemerhati Keluarga adalah memberikan pendampingan bagi keluarga-keluarga yang membutuhkan dukungan psikologis dan rohani. Para konselor awam diharapkan dapat menjadi teman untuk berbagi cerita, memberikan dukungan dan motivasi agar para keluarga yang sedang mengalami disfungsi dapat bangkit mengatasi masalahnya.

Untuk mendukung dan melengkapi peran dan fungsi dari Komunitas Pemerhati Keluarga tersebut, KAJ melalui KOM-KK berusaha membekali para konselor awam tersebut dengan pengetahuan dasar konseling, baik dalam bentuk teori maupun praktik. Ketrampilan konseling dasar yang diharapkan dapat dikuasi oleh para konselor awam adalah kemampuan mendengarkan keluhan konseli, mengidentifikasikan masalah yang dihadapi keluarga, mendampingi dan memotivasi para keluarga agar mampu mengatasi masalahnya, dan bila perlu membantu merujukkan pada profesional jika kasus yang dihadapi memang membutuhkan penanganan profesional.

Konseling itu sendiri dapat didefinisikan sebagai suatu tindakan yang dilakukan untuk membantu konseli yang memiliki masalah agar dapat kembali berfungsi normal (Kottler \& Brown, 1996 dalam Sommers-Flanagan \& Sommers-Flanagan, 2015). Sedangkan hasil akhir dari konseling itu sendiri adalah terjadinya perubahan dalam perilaku seseorang, yaitu pemberdayaan individu sehingga dapat mengatasi masalahnya (Gunarsa, 1992; Geldard \& Geldard, 2005; Burke, 1989 dalam Sommers-Flanagan \& Sommers-Flanagan, 2015). Adapun tujuan konseling adalah membantu konseli untuk mengidentifikasi masalah yang sedang dihadapi agar dapat mencari cara penyelesaian yang tepat, hingga akhirnya konseli dapat berfungsi kembali dengan normal, hidup lebih efektif dan dapat menyesuaikan diri dengan tuntutan lingkungan (Gunarsa, 1992).

Terdapat 7 hal yang perlu diperhatikan dari proses konseling (Ivey, Ivey, \& Zalaquett, 2010; Geldard \& Geldard, 2005; Hersen \& Van Hasselt, 1998; Lukas, 1993), antara lain: (a) adanya hubungan antara orang yang mencari pertolongan dan yang menolong. Dalam setiap sesi pertemuan konseling, konselor dan konseli secara bertahap akan saling belajar untuk menerima satu sama lain; (b) konselor harus terlatih, artinya konselor perlu dibekali dengan pelatihanpelatihan yang memadai; (c) konselor harus memiliki keahlian dan kepribadian penolong, (d) konselor mendorong orang untuk belajar, karena proses konseling itu sendiri seperti sebuah proses belajar, dari tidak tahu menjadi tahu; (e) konselor membantu konseli memahami hubungan antara diri dengan permasalahan yang sedang dialaminya, sehingga konseli dapat melihat permasalahan secara menyeluruh; (f) konselor memancing cara-cara penyelesaian masalah yang lebih produktif, dan (g) konselor membantu konseli untuk menemukan insight (pemahaman baru) atas masalah yang sedang dihadapi.

Terdapat tujuh keterampilan dasar yang diperlukan untuk menjadi seorang konselor, antara lain: observasi, wawancara, empati, mendengarkan aktif, memparafrasekan jawaban konseli/klien, mengidentifikasikan masalah dan memberikan dukungan atau memberdayakan konseli (Satler, 1988; Geldard \& Geldard, 2005; Morrison, 2008; Ivey, Ivey \& Zalaquett, 2010; Varenhorst, 2010). Secara rinci akan diuraikan penjelasan untuk masing-masing ketrampilan tersebut dalam paparan berikut ini. 


\section{Keterampilan observasi}

Keterampilan observasi (Satler, 1988) adalah keterampilan mengamati, bukan sekedar melihat atau memandang. Mengamati bermakna memusatkan perhatian pada suatu obyek, berusaha menangkap detil dan memaknai detil tersebut sebagai informasi yang berharga. Dalam proses konseling, observasi digunakan untuk mengukur keselarasan antara cerita yang disampaikan oleh konseli dengan perilaku yang ditampakkan, ekspresi wajah dan emosi yang ditunjukkan oleh yang bersangkutan. Tipe observasi yang digunakan adalah observasi naratif yang berbentuk pencatatan secara kualitatif, dan event recording yang berbentuk pencatatan secara kuantitatif.

\section{Keterampilan wawancara}

Keterampilan wawancara (Ivey, Ivey \& Zalaquett, 2010; Morrison, 2008) adalah proses untuk mengumpulkan informasi dari seseorang, baik yang terkait dengan cerita pengalaman individu tersebut, ataupun yang berhubungan dengan kondisi psikologisnya (emosi, cara berpikir ataupun tindakannya). Proses mengumpulkan informasi ini dilakukan dengan cara bertanya. Keterampilan wawancara juga perlu didukung dengan keterampilan mendengarkan aktif dan kemampuan untuk memparafrasekan jawaban konseli.

\section{Keterampilan mendengarkan aktif}

Keterampilan mendengarkan secara aktif adalah kemampuan untuk memahami, merefleksikan dan mengintepretasikan kembali isi pembicaraan lawan bicara. Bukan sekedar aktifitas mendengarkan suara, kata atau kalimat namun mampu memahami ide secara tepat seperti pesan yang dimaksudkan oleh si pengirim pesan. Untuk menghindari kesalahpahaman kadang kala perlu dilakukan konfirmasi, terutama untuk pesan-pesan yang bersifat ambigu atau muatan idenya kurang lengkap. Keterampilan mendengarkan secara aktif juga meliputi kemampuan untuk mengamati sekaligus mengintepretasikan bahasa non-verbal (Geldard \& Geldard, 2005).

\section{Keterampilan empati}

Empati dapat dimaknakan sebagai keterampilan untuk merefleksikan dan memahami emosi, pemikiran, pengalaman dan perilaku konseli ditinjau dari sudut pandang konseli. Seorang konselor harus mampu memahami dan menghayati permasalahan konseli dari perspektif konseli. Kemampuan konselor memahami respon konseli berdasarkan cara pandang konseli akan memudahkan konselor memahami penyebab masalah yang dialami oleh konseli (Geldard \& Geldard, 2005; Ivey et al., 2010)

\section{Keterampilan parafrase}

Selain empati, keterampilan lain yang juga diperlukan adalah keterampilan memparafrasekan jawaban konseli, keterampilan untuk merefleksikan kembali kata-kata yang digunakan oleh konseli atau klien, baik yang terkait dengan isi cerita maupun yang berhubungan dengan perasaan agar konseli merasa dipahami oleh konselornya (Geldard \& Geldard, 2005).

\section{Keterampilan mengidentifikasi masalah}

Identifikasi masalah merupakan upaya untuk memahami jenis, karakteristik kesulitan atau masalah yang dihadapi konseli. Pengidentifikasian masalah dilakukan oleh konselor agar konselor dapat memahami permasalahan yang dialami oleh konseli dan dapat menemukan apa yang menjadi penyebab ketidaknyamanan psikologis tersebut (Geldard \& Geldard, 2005). 


\section{Keterampilan pemberdayaan konseli}

Pemberdayaan konseli adalah upaya untuk meningkatkan kondisi konseli agar dapat berfungsi kembali dengan baik, secara sosial, akademik maupun dalam konteks profesi. Upaya untuk memberdayakan konseli diawali dengan memberikan dukungan bagi konseli agar termotivasi untuk menemukan solusi dari masalahnya. Cara yang dapat dilakukan adalah mengenali apa yang menjadi kekuatan atau potensi yang dimiliki oleh konseli atau klien, yang kemudian akan dijadikan modal dasar bagi konseli untuk bertahan dan bangkit mengatasi masalahnya (Varenhorst, 2010).

\section{METODE}

\section{Metode Pelaksanaan}

Kegiatan pengabdian kepada masyarakat ini diberikan dalam bentuk pelatihan dasar-dasar ketrampilan konseling. Komponen pelatihan terdiri dari $60 \%$ teori dan pengetahuan tentang prinsip-prinsip dasar konseling, kemudian $40 \%$ merupakan praktik. Komponen teori yang akan disampaikan meliputi: (a) pengetahuan umum tentang konseling keluarga, (b) definisi, tujuan dan karakteristik pemerhati keluarga, (c) karakteristik bidang pelayanan pemerhati keluarga, (d) kesejahteraan dan peran pemerhati keluarga, (e) kode etik, (f) pendekatan humanistik dalam melakukan konseling, (g) mempelajari tahapan dan proses konseling. Sedangkan komponen praktik meliputi: (a) praktik keterampilan konseling meliputi observasi, wawancara, empati, mendengarkan aktif, memparafrasekan jawaban konseli; dan (b) latihan melakukan identifikasi masalah dan serta melakukan pemberdayaan konseli.

Tabel 1. Partisipasi Mitra dalam Pelaksanaan Kegiatan

\begin{tabular}{|c|c|c|c|}
\hline Tahap & Kegiatan & Peran Mitra & Peran Tim Pengusul \\
\hline 1. & $\begin{array}{l}\text { Sosialisasi program } \\
\text { kepada para konselor } \\
\text { awam. }\end{array}$ & $\begin{array}{l}\text { Membantu } \\
\text { mempromosikan } \\
\text { kegiatan tersebut melalui } \\
\text { warta gereja dan web } \\
\text { KAJ. Membantu } \\
\text { mengirimkan surat } \\
\text { pemberitahuan kepada } \\
\text { Pastor Paroki yang ada di } \\
\text { Jakarta dan sekitarnya. }\end{array}$ & (belum terlibat) \\
\hline 2. & $\begin{array}{l}\text { Proses pendaftaran } \\
\text { akan dibantu oleh tim } \\
\text { dari KOM-KK KAJ }\end{array}$ & $\begin{array}{l}\text { KOM-KK membuat link } \\
\text { pendaftaran, agar } \\
\text { mempermudah para } \\
\text { peserta dari paroki- } \\
\text { paroki. }\end{array}$ & (belum terlibat) \\
\hline 3. & $\begin{array}{l}\text { Pelaksanaan pelatihan } \\
\text { yang meliputi teori dan } \\
\text { praktik dengan total } \\
\text { masa pelatihan } 16 \text { jam }\end{array}$ & $\begin{array}{l}\text { Tim KOM-KK } \\
\text { menyediakan tempat } \\
\text { untuk pelatihan. }\end{array}$ & $\begin{array}{l}\text { - Menyampaikan materi dan } \\
\text { praktik } \\
\text { - Menyiapkan konsumsi } \\
\text { - Menyiapkan perlengkapan } \\
\text { alat tulis } \\
\text { - Menyiapkan handout } \\
\text { pelatihan }\end{array}$ \\
\hline 4. & $\begin{array}{l}\text { Evaluasi pelatihan } \\
\text { (pre-test/post-test) } \\
\text { untuk mengukur hasil } \\
\text { pemahaman peserta }\end{array}$ & & $\begin{array}{l}\text { - Menyiapkan alat ukur untuk } \\
\text { mengetahui progres hasil } \\
\text { belajar. }\end{array}$ \\
\hline
\end{tabular}


Metode pelaksanaan meliputi beberapa tahap, yaitu: (1) sosialisasi program kepada para konselor awam melalui warta gereja dan web KAJ yang dilakukan oleh tim KOM-KK KAJ. Selain itu proses sosialisasi dilakukan juga dengan mengirimkan surat pemberitahuan kepada paroki-paroki di Jakarta dan sekitarnya; (2) proses pendaftaran akan dibantu oleh tim dari KOM-KK KAJ; (3) pelaksanaan pelatihan yang meliputi teori dan praktik dengan total masa pelatihan 16 jam; (4) dalam pelaksanaan pelatihan akan dilakukan pre-test dan post-test untuk mengukur pemahaman peserta terhadap materi yang diberikan. Sedangkan kegiatan pelatihannya dilaksanakan dalam 2 hari, dengan pembagian: (a) hari pertama berisi muatan teori seluruhnya (100\% teori); (b) hari kedua terbagi dalam $20 \%$ teori, $80 \%$ praktik. Secara rinci akan diuraikan partisipasi mitra pada Tabel 1.

\section{HASIL DAN PEMBAHASAN}

\section{Hasil}

Secara umum kegiatan Pelatihan Konseling bagi Komunitas Pemerhati Keluarga sudah dilaksanakan dan berjalan dengan lancar. Untuk mengetahui sejauh mana pemahaman para peserta terhadap materi yang diberikan maka peserta diberikan uji pengetahuan yang merupakan evaluasi kognitif, dan evaluasi ini disampaikan sebanyak 2 kali, yaitu sebagai pretest dan posttest. Terdapat 2 tahap uji pengetahuan karena ada 2 materi dasar konseling yang disampaikan secara bertahap, yaitu: (a) pengetahuan yang bersifat umum tentang hal-hal yang terkait dengan ciri pelayanan sebagai konselor Pemerhati Keluarga dan pengetahuan umum tentang pendekatan kemanusiaan dalam proses konseling, serta kode etik; dan (b) pengetahuan yang secara khusus terkait dengan jenis-jenis teknik dasar konseling.

\section{Analisis pengetahuan tentang layanan konselor}

Hasilnya menunjukkan adanya perubahan yang signifikan antara hasil pretest dan posttest. Pada uji pengetahuan untuk materi yang pertama yaitu terkait dengan pengetahuan umum dapat diuraikan sebagai berikut:

Pertama, terdapat peningkatan skor rata-rata dari seluruh peserta (20 orang). Hasil Pretest menunjukkan nilai mean sebesar 5.8 sedangkan hasil akhir Postest meningkat tajam sehingga hasil skor rerata hasil Postest meningkatkan menjadi 8.1. Kedua, berdasarkan uji perbedaan menggunakan T-test, diperoleh hasil yaitu terdapat perbedaan skor yang signifikan antara Pretest dan Postest (nilai Sig.2-tailed $=0.000<0.05$ ). Berdasarkan hasil tersebut maka dapat dimaknakan bahwa terdapat perbedaan yang signifikan antara pengetahuan sebelum dan sesudah pemberian pengetahuan tentang layanan konselor (materi 1).

\section{Analisis pengetahuan jenis-jenis teknik dasar konseling}

Pada pelaksanaan uji pengetahuan untuk materi kedua ini, total jumlah peserta yang hadir adalah 17 orang peserta. Sebanyak 3 orang peserta mengajukan ijin tidak dapat mengikuti pelatihan pada hari kedua. Pada uji pengetahuan untuk materi yang kedua yaitu terkait dengan teori yang berhubungan dengan ragam keterampilan dasar dalam konseling. Hasil perhitungan mean pada hasil pretest (mean $=9.76$ ) memiliki selisih yang kecil bila dibandingkan dengan skor mean posttest $($ mean $=10.71)$. Hasil uji beda yang dilakukan menunjukkan bahwa tidak terdapat perbedaan skor yang signifikan antara Pretest dan Postest pada pemberian materi 2 (nilai Sig.2tailed $=0.060>0.05$ ). Berdasarkan hasil tersebut maka dapat dimaknakan bahwa tidak terdapat perbedaan pengetahuan yang signifikan antara sebelum dan sesudah pemberian pengetahuan jenisjenis teknik dasar konseling (materi 2). 


\section{Pembahasan}

Berdasarkan hasil uji beda tersebut menunjukkan bahwa para peserta telah memahami dengan baik materi yang diberikan selama pelatihan hari pertama, yaitu materi yang terkait dengan karakteristik pelayanan sebagai Konselor Pemerhati Keluarga, pengetahuan umum tentang konseling keluarga, karakteristik konselor awam, dan kode etik yang harus dijaga. Sedangkan hasil uji beda pada pemberian materi-2 menunjukkan tidak terdapat perbedaan pengetahuan yang signifikan antara sebelum diberi pelatihan (materi 2) dengan kondisi sesudah diberi pelatihan. Bila mengacu pada skor rata-rata awal (pretest) yang mencapai angka 9.76, skor awal yang tinggi ini menunjukkan bahwa peserta sudah mengetahui dan memahami materi yang diberikan pada pelatihan hari kedua.

Hal ini dimungkinkan terjadi karena peserta telah mendapatkan pengetahuan dasar pada hari pertama pelatihan. Materi tes yang diberikan pada hari kedua sebenarnya merupakan pendalaman mengenai jenis teknik konseling yang dasar-dasarnya sudah dijelaskan pada materi hari pertama. Oleh sebab itu saat peserta diberikan soal-soal pretest pada materi ke-2, pada dasarnya mereka telah memiliki pengetahuan dasar yang mereka peroleh pada pelatihan hari pertama. Hal lain yang diduga juga turut mempengaruhi pencapaian skor yang tinggi pada pelatihan hari ke-2, baik pada skor pretest dan posttest adalah masalah bentuk soal. Pada tes yang diberikan di hari kedua tersebut, digunakan bentuk soal pilihan ganda. Sedangkan bentuk soal yang digunakan pada tes hari pertama tersebut menggunakan bentuk soal isian singkat. Salah satu kelemahan dari bentuk soal pilihan ganda adalah sulit dibedakan apakah jawaban yang tepat dari peserta benar-benar menunjukkan penguasaan pengetahuan mereka ataukah hanya kebetulan saja peserta memberikan jawaban benar. Pada tahap pelatihan ini tidak dilakukan uji kompetensi karena para peserta belum mendapatkan kesempatan untuk mempraktekkan teori dan praktik pada kasus nyata.

\section{KESIMPULAN DAN SARAN}

Berdasarkan hasil uji beda pada hasil evaluasi kognitif terhadap materi pelatihan dapat disimpulkan bahwa program pelatihan telah berhasil memberikan pengetahuan tentang dasar-dasar konseling bagi konselor awam. Namun perlu waktu yang lebih panjang agar para peserta dapat mempraktikkan keterampilan konseling dan secara berkelanjutan terus menggunakannya dalam praktik.

Adapun saran-saran yang dapat diberikan, antara lain: (a) pretest dan posttest sebaiknya dilakukan untuk seluruh materi sekaligus, tidak perlu dilakukan per materi; (b) dalam menyusun bentuk soal pretest dan posttest sebaiknya tidak menggunakan pilihan ganda karena banyak kelemahan dari bentuk soal tersebut; (c) jika sasaran dari pelatihan adalah kompetensi maka perlu diberikan waktu untuk berlatih lebih banyak, sehingga perlu mempertimbangkan kembali lama waktu pelatihan yang harus dialokasikan.

\section{Ucapan Terima Kasih (Acknowledgement)}

Terima kasih kepada DPPM Universitas Tarumanagara yang telah memberikan dukungan finansial sehingga kegiatan PKM ini dapat terlaksana. Terima kasih pula kepada para peserta pelatihan yang telah bersungguh-sungguh berpartisipasi aktif dalam kegiatan PKM ini dan pihak KOM-KK KAJ yang telah membantu terlaksanannya kegiatan PKM sehingga dapat berjalan lancar. 


\section{REFERENSI}

Apriano, A. (2018). Pelayanan Bersama Komunitas Sebagai Model Pelayanan Pastoral Berbasis Paradigma Komunal-Kontekstual dalam Teologi Pastoral. Jurnal Teologi dan Pendidikan Agama Kristen, 4(2), 92-106

Geldard, D., \& Geldard, K. (2005). Basic personal counseling: A training manual for counselors. NSW, Australia: Person Education Australia.

Gunarsa, S.D. (1992). Konseling dan psikoterapi. Jakarta: PT. BPK Gunung Mulia.

Habur, A.M. (2018). Family Catechesis in the Digital Era. Jurnal Pendidikan dan Kebudayaan MISSIO, 10 (1), 39-47.

Hersen, M. \& Van Hasselt, V.B. (1998). Basic interviewing: A practical guide for counselor and clinicians. Mahwah, NJ: Lawrence Erlbaum Associates.

Ivey, A. E., Ivey, M. B., \& Zalaquett, C. P. (2010). Intentional interviewing and counseling: Facilitating client development in a multicultural society ( $7^{\text {th }}$ edition). Belmont, CA: Cengage Learning.

Keuskupan Agung Jakarta. (2018). Komisi Kerasulan Keluarga (KOM-KK). http://www.kaj.or.id/komisi/komisi-kerasulan-keluarga-kom-kk. 17 Maret 2019.

Lestari, S. (2012). Psikologi keluarga: Penanaman nilai dan penanganan konflik dalam keluarga. Jakarta: Kencana Prenada Media Group

Lukas, S. (1993). Where to start and what to ask: An assessment handbook. New York, NY: W.W. Norton \& Company, Inc.

Morrison, J. R. (2008). The first interview ( $3^{\text {rd }}$ ed.). New York, NY: The Guilford Press.

Samuel, P.S., Rillotta, F., \& Brown, I. (2012). The development of family qualitby of life concepts and measures. Journal of Intelectual Disability Research. 56 (1).1-16.

Sattler, J.M. (1988). Assesment of children. 3rd ed. San Diego, CA: Jerome M. Publisher

Soetjiningsih. (1995). Tumbuh kembang anak. Jakarta: Penerbit Buku Kedokteran EGC.

Sommers-Flanagan, J., \& Sommers-Flanagan, R. (2015). Counseling and psychotherapy theories in context and practice: Skills, strategies, and techniques. Hoboken, NJ: John Wiley \& Sons.

Tim Pusat Pendampingan Keluarga "Brayat Minulyo". (2007). Kursus Persiapan Hidup Perkawinan. Yogyakarta: Penerbit Kanisius

Varenhorst, B.B., (2010). Training peer helper: Coaching youth to communicate, solve problems, and make decisions. Minneapolis, MN: Search Institute Press. 